\title{
"What are the effects of diagnostic imaging on clinical outcomes in patients with low back pain presenting for chiropractic care? A matched observational study." Jenkins et al., Chiropractic \& Manual Therapies 2021;29:46
}

\author{
Mark A. Lopes ${ }^{*}$ (1)
}

\section{Dear Editor,}

Studies such as the one that is the subject of this letter to the editor [1] are important, and I commend the authors for their efforts. Their conclusions were that diagnostic imaging did not result in better outcomes. However, as described in the article, the findings from the paper support a more limited conclusion, such as "imaging did not appear to improve outcomes when used in an unspecified manner." We are left to make assumptions regarding how imaging was used to influence treatment, if at all.

The primary purpose of imaging, as described, was apparently to rule out red flags, which is also supported by the $24 \%$ referral rate for imaging. Imaging alone cannot be expected to produce different outcomes between those that received imaging and those that didn't.

This study did not control or describe treatment specifically or address how and to what extent imaging was used to inform treatment decisions. The patients in both the imaging group and the non-imaging group may or may not have been treated similarly. We cannot, therefore, suggest from this study that the lack of difference in outcomes between groups was due to the lack of additional benefits of treatment informed by imaging.
*Correspondence: lopeschiro@yahoo.com

Gonstead Clinical Studies Society, 2107 Forest Ave, Suite 130, Chico, CA 95928, USA
I hope others continue such studies, but there is a need to describe how imaging was used to inform treatment in order to determine whether or not imaging is useful for biomechanical or other assessments prior to treatment if imaging is to be used beyond red-flag purposes.

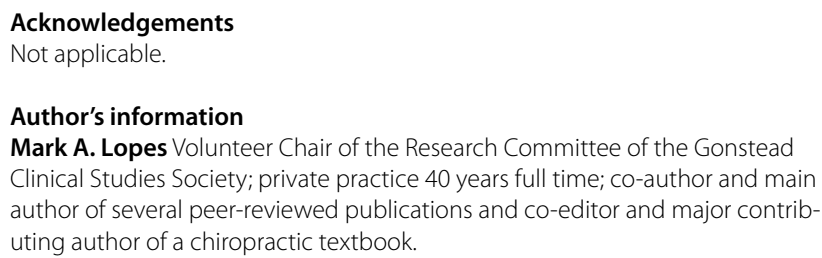
author of several peer-reviewed publications and co-editor and major contributing author of a chiropractic textbook.

\section{Authors' contributions}

$M L$ is the sole contributor to this letter.

Funding

Not applicable.

\begin{abstract}
Availability of data and materials Not applicable.
\end{abstract}

\section{Declarations}

Ethical approval and consent to participate Not applicable.

Consent for publication Not applicable.

Competing interests

The author declares that he has no competing interests. permits use, sharing, adaptation, distribution and reproduction in any medium or format, as long as you give appropriate credit to the original author(s) and the source, provide a link to the Creative Commons licence, and indicate if changes were made. The images or other third party material in this article are included in the article's Creative Commons licence, unless indicated otherwise in a credit line to the material. If material is not included in the article's Creative Commons licence and your intended use is not permitted by statutory regulation or exceeds the permitted use, you will need to obtain permission directly from the copyright holder. To view a copy of this licence, visit http://creativecommons.org/licenses/by/4.0/. The Creative Commons Public Domain Dedication waiver (http://creativecommons.org/publicdomain/zero/1.0/) applies to the data made available in this article, unless otherwise stated in a credit line to the data. 
Received: 26 January 2022 Accepted: 16 February 2022

Published online: 01 March 2022

\section{Reference}

1. Jenkins HJ, Kongsted A, French SD, et al. What are the effects of diagnostic imaging on clinical outcomes in patients with low back pain presenting for chiropractic care? A matched observational study. Chiropr Man Therap. 2021;29:46.

\section{Publisher's Note}

Springer Nature remains neutral with regard to jurisdictional claims in published maps and institutional affiliations.

- fast, convenient online submission

- thorough peer review by experienced researchers in your field

- rapid publication on acceptance

- support for research data, including large and complex data types

- gold Open Access which fosters wider collaboration and increased citations

- maximum visibility for your research: over $100 \mathrm{M}$ website views per year

At BMC, research is always in progress.

Learn more biomedcentral.com/submissions 